\title{
HUBUNGAN LAMA MENDERITA DIABETES MELLITUS TIPE II DENGAN KEJADIAN KOMPLIKASI POLINEUROPATI DIABETIK DI WILAYAH KERJA PUSKESMAS ANTANG PERUMNAS KECAMATAN MANGGALA KOTA MAKASSAR
}

The Correlation ot the duration of Diabetes Mellitus Type II With Diabetic Polyneuropathy Complications Incidence At Antang Perumnas Public Health Center ManggalaSub-Distric Makassar

\author{
Mukhlishah Nurul Khair ${ }^{1}$, Naharia La Ubo' ${ }^{2}$, Nuraeni Mustari ${ }^{3}$ \\ 'Politeknik Kesehatan Kementrian Kesehatan Makassar \\ lisakhaer@gmail.com 082363222742
}

\begin{abstract}
Diabetic polyneuropathy is one of the complications illustrating the extent of peripheral nerve involvement and generally bilateral symmetrical distribution including sensory, motor and autonomic disorders. The study aimed to determine the long association of type II diabetes mellitus with the incidence of complications of diabetic polyneuropathy in the Work Area of the Antang Perumnas Health Center, Manggala District, Makassar City. This study was designed with an analytical descriptive method using a cross-sectional design and using Chi-Square Test. The sampling technique in this study uses Purposive Sampling. The results of the study were $p=0.004$, there was a long association with type II diabetes mellitus with the incidence of diabetic polyneuropathy. This study concluded that there was a significant relationship between the duration of suffering from type II diabetes mellitus and the incidence of diabetic polyneuropathy. It is better if people with diabetes mellitus can maintain blood glucose control and do the best foot care under what is recommended by health workers and carry out healthy living behaviours with diabetes mellitus.
\end{abstract}

Keywords : Diabetic Polyneuropathy, Long Suffenring of DM

\section{ABSTRAK}

Polineuropati diabetik merupakan salah satu komplikasi yang menggambarkan banyaknya keterlibatan saraf tepi dan distribusi umumnya bilateral simetris meliputi gangguan sensorik, motorik maupun otonom. Tujuan penelitian untuk mengetahui hubungan lama menderita diabetes mellitus tipe II dengan kejadian komplikasi polineuropati diabetik di Wilayah Kerja Puskesmas Perumnas Antang, Kecamatan Manggala, Kota Makassar. Sampel penelitian berjumlah 31 responden. Teknik pengambilan sampel yang digunakan adalah accidental. Penelitian ini dirancang dengan metode deskriptif analitik menggunakan desain cross sectional dan menggunakan Uji Chi Square. Hasil penelitian dengan $p=0.004$, yang berarti ada hubungan lama menderita diabetes mellitus tipe II dengan kejadian komplikasi polineuropati diabetik. Semakin lama seseorang menderita diabetes mellitus tipe II maka semakin besar pula resiko komplikasi polineuropati diabetik yang terjadi.

Kata Kunci : Lama menderita DM, polineuropati diabetik

\section{PENDAHULUAN}

Diabetes mellitus adalah suatu penyakit kronis yang terjadi ketika kelenjar pankreas tidak dapat memproduksi hormon insulin yang cukup, atau ketika tubuh tidak dapat menggunakan hormon insulin secara efektif. (WHO, 2018). Penyakit diabetes mellitus merupakan penyakit sistemik karena dapat mempengaruhi berbagai sistem dalam tubuh. Menurut JM Baena, diabetes mellitus merupakan gangguan metabolisme yang ditandai dengan kadar glukosa darah yang tinggi. Kadar glukosa darah yang tinggi secara terus menerus dapat menyebabkan kerusakan pembuluh darah yang akan mempengaruhi jantung, mata, ginjal, dan saraf dan mengakibabtkan berbagai komplikasi (JM Baena-Diez, 2016).

Di samping itu, penyakit diabetes mellitus merupakan masalah kesehatan yang besar, hal ini disebabkan terjadinya peningkatan jumlah penderita

diabetes dari tahun ke tahun di seluruh dunia. Pada tahun 2015, terdapat sekitar 415 juta orang dewasa hidup dengan diabetes, kenaikan sebanyak 4 kali lipat dari 108 juta di tahun 1980an. Bila tidak ada tindakan pencegahan maka jumlah ini akan terus meningkat dan diperkirakan pada tahun 2040 menjadi 642 juta penderita (International Diabetes Federation, 2015)

IDF Atlas 2017 melaporkan Indonesia menempati peingkat keenam sebagai negara dengan penyandang diabetes melitus tertinggi setelah China, India, Amerika Serikat, Brazil, Rusia dan Meksiko dengan jumlah penyandang diabetes usia 20-79 tahun sekitar 10,3 juta orang (IDF, 2017).

Penyakit diabetes mellitus di Sulawesi Selatan juga mengalami peningkatan dari tahun ke tahun. Menurut Riset Kesehatan Dasar (Riskesdas) Tahun 2013, prevalensi diabetes di Sulawesi Selatan 
yang terdiagnosis oleh dokter sebesar $1,6 \%$ dan di tahun 2018 meningkat menjadi 1,8\% (Riskesdas, 2018).

Di Kota Makassar, jumlah penyakit diabetes mellitus pada tahun 2014 sebanyak 1.894 orang, kemudian meningkat di tahun 2015 menjadi 5.700 orang, dan data terakhir pada tahun 2016 terdapat 4.555 orang penderita diabetes mellitus (Dinas Kesehatan, 2016).

Berdasarkan data sekunder Puskesmas Antang Perumnas, Kecamatan Manggala, Kota Makassar menunjukkan bahwa jumlah pasien yang menderita Diabetes Melitus pada tahun 2017 sebanyak 1.133 kunjungan dan pada tahun 2018 sebanyak 1.228 kunjungan. Data kunjungan pada bulan Desember 2018 sebanyak 114 orang. Hal ini menunjukkan terjadinya peningkatan kejadian diabetes mellitus di Puskesmas Antang Perumnas (Medical Record Puskesmas Antang Perumnas, 2018).

Salah satu komplikasi diabetes mellitus yang paling sering terjadi adalah neuropati diabetik. Ada beberapa manifestasi klinik neuropati ternasuk di antaranya mononeuropati ataupun polineuropati. Pada pasien diabetes mellitus lebih banyak ditemukan polineuropati sensoris distalis. Polineuropati diabetik menggambarkan keterlibatan banyak saraf tepi dan distribusinya umumnya bilateral simetris meliputi gangguan sensorik, motoric, maupun autonom (Subekti, 2014).

Dalam penelitian yang dilakukan oleh Aghniya (2017) yang berjudul hubungan lama menderita diabetes mellitus dengan terjadinya komplikasi neuropati, hasilnya menunjukkan terdapat hubungan yang signifikan antara lamanya menderita diabetes mellitus dengan terjadinya komplikasi diabetik peripheral neuropathy.

Faktor-faktor yang berhubungan dengan neuropati menurut (Black, JM \& Hawks, 2009) antara lain yakni insufisiensi pembuluh darah, peningkatan kadar gula darah, dan faktor metabolik. Teori lain menyatakan bahwa faktor resiko lain yang dapat menyebabkan neuropati diabetik menurut (Katulanda et al, 2012) antara lain peningkatan umur, lama waktu menderita DM, dan rendahnya kontrol gula darah.

Berdasarkan uraian-uraian di atas peneliti tertarik untuk melakukan penelitian tentang hubungan lama menderita diabetes mellitus tipe II dengan kejadian komplikasi polineuropati diabetik yang akan dilakukan di Puskesmas Antang Puskesmas Kota Makassar.

\section{METODE}

\section{Desain, Tempat dan Waktu}

Penelitian ini merupakan penelitian kuantitatif dengan desain penelitian deskriptif analitik yaitu mencari adanya hubungan dua variabel dengan pendekatan cross sectional. Penelitian ini dilakukan di Wilayah Kerja Puskesmas Antang Perumnas Kota Makassar, yag di lakukan bulan Maret sampai Juli 2019.

\section{Jumlah dan Cara Pengambilan Subjek}

Pegambilan sampel menggunakan teknik accidental, berdasarkan jumlah yang sampel yang diperoleh yang ada/ tersedia waktu itu, responden yang didapatkan untuk dijadikan sampel berjumlah 31 responden.

Tahap awal penelitian melalui prosedur pengujian etika penelitian oleh Unit Etika Penelitian Medis dan Kesehatan di Kampus Poltekkes Makassar. Penelitian ini telah memperoleh sertifikat kelulusan Uji Etika Penelitian dengan nomor surat No. 795/KEPK-PTKMKS/VI/2019). Setelah mendapat surat lolos Uji Etik, selanjutnya peneliti meminta izin pada piak puskesmas sudiang untuk melakukan penelitian setelah itu melakukan pengumpulan data menggunakan kuesioner demografi dan pemeriksaan Diabetic Neuropathy Symptom (DNS) melalui teknik wawancara.

Diabetic Neuropathy Symptom (DNS) merupakan pemeriksaan sederhana berisi 4 poin yang bernilai untuk skor gejala yang dirasakan. Keempat gejala yang dimaksud adalah jalan tidak stabil, nyeri neuropatik atau terbakar, sensasi tusukan, serta mati rasa dengan skor maksimal sebesar 4 poin. 0 poin menandakan tidak terjadi neuropati diabetik dan 1-4 poin menandakan terjadi neuropati diabetik.

Data yang telah dikumpulkan selanjutnya diolah dengan menggunakan SPSS. Adapun analisis data yang digunakan dalam penelitian ini adalah analisis univariat dan bivariat. Analisis univariat dilakukan terhadap tiap variabel dari hasil penelitian. Analisis univariat digunakan untuk mendapatkan gambaran tentang distribusi responden berdasarkan jenis kelamin, kejadian diabetes mellitus dan golongan darah. Analisis Bivariat menggunakan Chi Square.

\section{HASIL}

Hasil penelitian terdiri dari analisis univariate dan bivariate. Pada analisis univariate bertujuan untuk mengetahui gambaran distribusi variabel data demografi responden. Pada analisis bivariat bertujuan untuk mengetahui hubungan antara lama menderita diabetes mellitus dengan kejadian komplikasi polineuropati diabetik.

\section{Analisis Univariat Data Demografi Jenis Kelamin}

Berdasarkan penelitian yang dilakukan terhadap 31 orang responden, didapatkan ketegori jenis kelamin penderita diabetes mellitus tipe II: 
Tabel 4.1

Distribusi Frekuensi Responden Menurut Jenis Kelamin di Puskesmas Antang Perumnas Tahun 2019

\begin{tabular}{lcc}
\hline $\begin{array}{c}\text { Jenis } \\
\text { Kelamin }\end{array}$ & Frekuensi (n) & $\begin{array}{c}\text { Persentase } \\
(\%)\end{array}$ \\
\hline Perempuan & 25 & 80,6 \\
\hline Laki-Laki & 6 & 19,4 \\
\hline Total & $\mathbf{3 1}$ & $\mathbf{1 0 0 , 0}$ \\
\hline Sumber: Data Primer 2019 & &
\end{tabular}

Berdasarkan tabel 4.1 di atas menunjukkan bahwa dari 31 jumlah responden paling banyak yang berjenis kelamin perempuan 25 orang $(80,6 \%)$ dari pada yang berjenis kelamin laki-laki sebanyak 6 orang $(19,4 \%)$.

Umur

Berdasarkan penelitian yang dilakukan terhadap 31 orang responden, didapatkan ketegori umur penderita diabetes mellitus tipe II.

Tabel 4.2

Distribusi Frekuensi Responden Menurut Umur di Puskesmas Antang Perumnas Tahun 2019

\begin{tabular}{lcc}
\hline \multicolumn{1}{c}{ Umur } & $\mathbf{F ~ ( n )}$ & $\begin{array}{c}\text { Persentase } \\
(\mathbf{\%})\end{array}$ \\
\hline 45-49 tahun & 4 & 12,9 \\
\hline 50-54 tahun & 5 & 16,1 \\
\hline 55-59 tahun & 10 & 32,3 \\
60-64 tahun & 12 & 38,7 \\
\hline Total & $\mathbf{3 1}$ & $\mathbf{1 0 0 , 0}$ \\
\hline Sumber: Data Primer 2019 &
\end{tabular}

Berdasarkan tabel $4.1 \mathrm{di}$ atas menunjukkan bahwa dari 31 jumlah responden yang terbanyak pada rentang umur 60-64 tahun sebanyak 12 orang $(38,7 \%)$, sedangkan yang paling sedikit pada rentang umut $45-49$ tahun sebanyak 4 orang $(12,9 \%)$,

\section{Pendidikan}

Tabel 4.3

Distribusi Frekuensi Responden Menurut Pendidikan di Puskesmas Antang Perumnas Tahun 2019

\begin{tabular}{lcc}
\hline Pendidikan & F (n) & $\begin{array}{c}\text { Persentase } \\
(\%)\end{array}$ \\
\hline SD & 2 & 6,5 \\
\hline SMP & 10 & 32,3 \\
\hline SMA & 13 & 41,9
\end{tabular}

\begin{tabular}{lcc}
\hline $\begin{array}{l}\text { Perguruan } \\
\text { Tinggi }\end{array}$ & 6 & 19,4 \\
\hline Total & 31 & 100,0 \\
\hline Sumber: Data Primer 2019 & &
\end{tabular}

Berdasarkan tabel 4.3 di atas menunjukkan bahwa dari 31 jumlah responden terbanyak adalah yang berpendidikan SMA sebanyak 13 orang $(41,9 \%)$ dan yang paling sedikit adalah yang berpendidikan SD sebanyak 2 orang $(6,5 \%)$.

\section{Kadar Gula Darah}

Berdasarkan penelitian yang dilakukan terhadap 31 orang penderita, didapatkan ketegori kadar gula darah penderita diabetes mellitus tipe II.

Tabel 4.4

Distribusi Frekuensi Responden Menurut Kadar Gula Darah di Puskesmas Antang Perumnas Tahun 2019

\begin{tabular}{lcc}
\hline $\begin{array}{c}\text { Kadar Gula } \\
\text { Darah }\end{array}$ & Frekuensi (n) & $\begin{array}{c}\text { Persentase } \\
(\%)\end{array}$ \\
\hline $80-126 \mathrm{mg} / \mathrm{dL}$ & 7 & 22,6 \\
\hline$>126 \mathrm{mg} / \mathrm{dL}$ & 24 & 77,4 \\
\hline Total & 31 & 100,0 \\
\hline
\end{tabular}

Sumber: Data Primer 2019

Berdasarkan tabel 4.4 di atas menunjukkan bahwa dari 31 jumlah responden sebagian besar memiliki kadar gula darah darah $>126$ mgdL sebanyak 24 orang $(77,4 \%)$ sedangkan pada rentang 80-126 mg/dL sebanyak 7 orang $(80,6 \%)$.

\section{Analisis Univariat}

Dalam analisis univariat dihasilkan distribusi frekuensi (jumlah dan persentase) dari masingmasing ketegori variabel independen dan dependen yaitu lama menderita diabetes mellitus dan kejadian komplikasi polineuropati dan yang ditampilkan dalam bentuk tabel.

a. Lama Menderita Diabetes Mellitus

Berdasarkan penelitian yang dilakukan terhadap 31 orang penderita, didapatkan ketegori lama menderita diabetes mellitus tipe II: 
Tabel 4.5

Distribusi Frekuensi Responden Menurut Lama Menderita Diabetes Melitus di Puskesmas Antang Perumnas Tahun 2019

\begin{tabular}{lcc}
\hline $\begin{array}{c}\text { Lama } \\
\text { Menderita } \\
\text { DM }\end{array}$ & $\mathbf{F ~ ( n )}$ & $\begin{array}{c}\text { Persentase } \\
(\%)\end{array}$ \\
\hline$\leq 5$ tahun & 7 & 22,6 \\
\hline$>5$ tahun & 24 & 77,4 \\
\hline Total & 31 & 100,0
\end{tabular}

Sumber: Data Primer 2019

Berdasarkan tabel 4.5 di atas menunjukkan bahwa dari 31 jumlah responden sebagian besar menderita diabetes melitus selama $>5$ tahun yaitu sebanyak 24 orang $(77,4 \%)$ dan $\leq 5$ tahun sebanyak 7 orang $(22,6 \%)$.

\section{Kejadian Komplikasi Polineuropati}

Berdasarkan penelitian yang dilakukan terhadap 31 orang penderita, didapatkan ketegori kejadian komplikasi polineuropati diabetik pada penderita diabetes mellitus tipe II.

Tabel 4.6

Distribusi Frekuensi Responden Menurut Kejadian Komplikasi Polineuropati di Puskesmas Antang Perumnas Tahun 2019

\begin{tabular}{lcc}
\hline $\begin{array}{c}\text { Komplikasi } \\
\text { Polineuropati }\end{array}$ & $\mathbf{F}(\mathbf{n})$ & $\begin{array}{c}\text { Persentase } \\
(\%)\end{array}$ \\
\hline Negatif & 6 & 19,4 \\
\hline Positif & 25 & 80,6 \\
\hline Total & 31 & 100,0
\end{tabular}

Sumber: Data Primer 2019

Berdasarkan tabel 4.6 di atas menunjukkan bahwa dari 31 jumlah responden sebagian besar mengalami komplikasi polineuropati diabetik yaitu sebanyak 25 orang $(80,6 \%)$ dan yang tidak mengalami komplikasi sebanyak 6 orang $(19,4 \%)$.

\section{Analisa Bivariat}

Analisa bivariat yaitu menganalisis hubungan lama menderita diabetes mellitus dengan kejadian komplikasi polineuropati diabetik dengan menggunakan uji analisis berupa Chi Square. Hubungan lama menderita diabetes mellitus tipe II dengan kejadian Komplikasi Neuropati Diabetik dapat dilihat pada tabel 4.7

Tabel 4.7

Hubungan Lama Menderita Dengan Kejadian Komplikasi Polineuropati

Sumber: Data Primer 2019

\begin{tabular}{|c|c|c|c|c|c|c|c|}
\hline \multirow{3}{*}{$\begin{array}{c}\text { Lama } \\
\text { Mend } \\
\text { erita } \\
\text { DM }\end{array}$} & \multicolumn{4}{|c|}{$\begin{array}{c}\text { Kejadian } \\
\text { Polineuropati }\end{array}$} & \multirow{2}{*}{\multicolumn{2}{|c|}{ Total }} & \multirow{3}{*}{$\begin{array}{c}P \\
\text { Value }\end{array}$} \\
\hline & \multicolumn{2}{|c|}{$\begin{array}{l}\text { Tidak } \\
\text { Terjadi }\end{array}$} & \multicolumn{2}{|c|}{ Terjadi } & & & \\
\hline & $F$ & $\%$ & $f$ & $\%$ & $f$ & $\%$ & \\
\hline $\begin{array}{l}\leq 5 \\
\text { tahun }\end{array}$ & 4 & $\begin{array}{c}12,9 \\
\%\end{array}$ & 3 & $\begin{array}{c}9,7 \\
\%\end{array}$ & 7 & $\begin{array}{c}22,6 \\
\%\end{array}$ & \\
\hline $\begin{array}{l}>5 \\
\text { tahun }\end{array}$ & 2 & $\begin{array}{l}6,5 \\
\%\end{array}$ & 22 & $\begin{array}{c}71,0 \\
\%\end{array}$ & 24 & $\begin{array}{c}77,4 \\
\%\end{array}$ & 0.004 \\
\hline Total & 6 & $\begin{array}{c}19,4 \\
\%\end{array}$ & 25 & $\begin{array}{c}80,6 \\
\%\end{array}$ & 31 & $\begin{array}{c}100 \\
\%\end{array}$ & \\
\hline
\end{tabular}

Berdasarkan tabel 4.7 diperoleh hasil bahwa kejadian komplikasi polineuropati diabetik lebih banyak terjadi pada penderita yang mengalami diabetes $>5$ tahun yaitu 22 orang $(71,0 \%)$ dibandingkan pada penderita yang mengalami diabetes melitus $\leq 5$ tahun hanya 3 orang penderita $(9,7 \%)$

\section{PEMBAHASAN}

Jenis kelamin responden berdasarkan hasil penelitian menunjukkan responden perempuan lebih banyak daripada laki-laki dengan jumlah perempuan sebanyak 25 orang dan laki-laki sebanyak 6 orang. Perempuan memiliki kecenderungan mengalami obesitas dibandingkan laki-laki. Hal ini sejalan dengan teori yang mengatakan perempuan memiliki LDL atau kolesterol jahat tingkat trigliserida yang lebih tinggi dibandingkan dengan laki-laki. Jumlah lemak pada laki-laki dewasa rata-rata berkisar antara $15-20 \%$ dari berat badan total, dan pada perempuan sekitar $20-25 \%$. Jadi peningkatan kadar lipid (lemak darah) pada perempuan lebih tinggi dibandingkan pada laki-laki, sehingga faktor risiko terjadinya diabetes mellitus pada perempuan 3-7 kali lebih tinggi dibandingkan pada laki-laki yaitu 2-3 kali (Haryati dan Geria, 2014). Hasil penelitian ini juga sejalan dengan penelitian yang dilakukan Susanto dan Suyanto (2016) hasil penelitiannya menunjukkan bahwa jenis kelamin perempuan sebanyak 46 dan laki-laki sebanyak 33 dari hasil penelitiannya 
menunjukkan bahwa jenis kelamin penderita diabetes melitus yang paling dominan adalah jenis kelamin perempuan.

Umur responden berdasarkan hasil penelitian menunjukkan responden terbanyak berada pada rentang umur 60-64 tahun. Hasil penelitian ini sejalan dengan penelitian yang dilakukan oleh Prima dan Achmad (2018) hasil penelitiannya menunjukkan bahwa umur responden $>60$ tahun dengan diabetes melitus tipe 2 sebanyak 18 orang dan umur responden 45-49 tahun dengan diabetes melitus sebanyak 9 orang. Hasil penelitian menunjukkan bahwa responden yang berumur $>60$ tahun lebih banyak dibandingkan dengan responden yang berumur 45-49 tahun.

Pendidikan responden berdasarkan hasil penelitian menunjukkan bahwa sebagian besar responden berpendidikan SMA. Hal ini dapat dijelaskan bahwa pendidikan yang paling banyak saat melakukan penelitian adalah pendidikan SMA. Hasil penelitian sejalan dengan penelitian yang dilakukan oleh Rifke Debora dkk (2017), hasil penelitiannya menunjukkan bahwa pendidikan rendah sebanyak 44 orang dan pendidikan tinggi sebanyak 10 orang.

Dari 31 orang penderita diabetes melitus tipe II di wilayah Puskesmas Antang Perumnas kebanyakan responden memiliki kadar gula darah yang memiliki kadar gula darah $>126 \mathrm{mg} / \mathrm{dL}$ sebanyak 20 orang sedangkan penderita dengan kadar gula darah pada kisaran 80-125 mg/dL sebanyak 7 orang. Hal ini menunjukkan lebih dari separuh penderita diabetes melitus memiliki kadar gula darah lebih $>126 \mathrm{mg} / \mathrm{dL}$.

Berdasarkan hasil penelitian yang diperoleh dari 31 responden yang menderita diabetes mellitus tipe II menunjukkan bahwa lebih dari separuh responden menderita diabetes mellitus $>5$ tahun. Sedangkan respoden dengan lama menderita $<5$ tahun hanya 7 orang.

Hasil penelitian sejalan dengan penelitian yang dilakukan oleh Gumilang Mega P (2014), hasil penelitiannya menunjukkan bahwa sebanyak 25 orang menderita diabetes melitus tipe 2 selama 5-10 tahun. Dari hasil penelitian ini menunjukkan bahwa lama menderita diabetes selama 5-10 tahun lebih banyak dibandingkan $<5$ tahun. Penelitian yang dilakukan oleh Yusra (2011) juga menunjukkan ratarata responden pada pasien diabetes mellitus dalam penelitiannya memiliki lama menderita $>5$ tahun.

Berdasarkan hasil penelitian yang diperoleh menunjukkan bahwa kejadian komplikasi polineuropati diabetik lebih banyak terjadi pada penderita yang mengalami diabetes $>5$ tahun yaitu 22 orang dibandingkan pada penderita yang mengalami diabetes melitus $\leq 5$ tahun yang hanya 3 orang penderita.

\section{Hubungan Lama Menderita Dengan Kejadian}

\section{Komplikasi Polineuropati}

Melalui uji analisis Chi Square diperoleh nilai $P_{\text {value }}=0.004$ yang artinya lebih kecil dari nilai $a=$ 0,05 . Kriteria pengujian adalah bila $P_{\text {value }} \leq$ alpha dengan derajat kepercayaan $5 \%(0,05)$. Maka $\mathrm{H}_{0}$ ditolak dan $\mathrm{Ha}$ diterima yang artinya ada hubungan lama menderita diabetes mellitus tipe II dengan kejadian komplikasi polineuropati diabetik.

Hasil penelitian ini sesuai dengan teori yang menyatakan bahwa lama menderita diabetes merupakan salah satu faktor terjadinya komplikasi neuropati. Awal terjadinya diabetes mellitus akan mempengaruhi serabut saraf kecil yang kemudian seiring dengan durasi atau lamanya menderita akan diikuti oleh serabut saraf besar dan berhubungan dengan berkurangnya kecepatan hantar saraf (Sumner et.al 2003).

Dari 31 responden penelitian didapati 22 orang yang mengalami komplikasi polineruopati dengan lama menderita $>5$ tahun. Hal ini sejalan dengan teori Smeltzer (2008) yang mengatakan lama terdiagnosa DM berkaitan dengan penurunan fungsi sel beta pankreas sehingga akan menimbulkan komplikasi yang secara umum terjadi pada pasien dengan lama sakit 5-10 tahun. Maka dapat disimpulkan di sini bahwa semakin lama seseorang menderita diabetes mellitus tipe II maka semakin besar pula resiko komplikasi polineuropati diabetik yang terjadi.

Hasil penelitian ini sejalan dengan penelitian yang pernah dilakukan oleh Aghniya (2017) tentang "Hubungan Lamanya Menderita Diabetes Mellitus dengan Terjadinya Diabetic Peripheral Neuropathy pada Pasien Diabetes Mellitus tipe II di GRHA Diabetika Surakarta". Metode yang digunakan yakni metode penelitian observasional dengan desain cross sectional dengan jumlah sampel sebanyak 100 orang yang merupakan pasien diabetes mellitus di GRHA Diabetika Surakarta.. Hasil penelitian terdapat hubungan yang signifikan antara lamanya menderita diabetes mellitus dengan terjadinnya diabetic pheriperal neuropathy pada pasien diabetes mellitus tipe II dengan $(p=0,0001)$ dan nilai Odd Ratio (OR) 0,25 yang berarti semakin lama durasi diabetes mellitus maka resiko terjadinya diabetic peripheral neuropathy meningkat sebanyak $25 \%$. Perbedaan penelitian ini dengan penelitian tersebut adalah dalam variabel, unit analisa data, jumlah dan populasi sampel serta waktu dan tempat penelitian.

Namun pada penelitian ini dari 31 responden didapati 3 orang dengan lama menderita kurang dari 5 tahun yang mengalami komplikasi polineuropati dan terdapat 2 orang dengan lama menderita lebih dari 5 tahun yang tidak mengalami komplikasi. Hal ini bisa terjadi karena tingkat pendidikan responden yang bervariasi dan masih ada yang tingkat pendidikannya rendah sehingga 
dapat mempengaruhi pengetahuannya dalam menerapkan gaya hidup sehat.

Jika mereka memahami dan mampu menerapkan gaya hidup sehat dengan diabetes maka resiko terjadinya komplikasi dapat dihindari walaupun sudah lama menderita. Begitupun sebaliknya meskipun seseorang belum lama menderita diabetes, ia dapat mengalami komplikasi bila tidak dilakukan pengelolaan diabetes dan menerapkan gaya hidup sehat.

Sejalan dengan teori yang diungkapkan Lemone, Priscilla (2015) bahwa setiap orang, setiap jenjang usia dan setiap lapisan masyarakat yang menderita diabetes melitus akan mengalami komplikasi jika pengendalian diabetes melitus tidak dilakukan dengan baik (LeMone, Pricsilla 2015).

Dari penelitian ini dapat dilihat bahwa seseorang dapat mengalami komplikasi meskipun belum lama menderita diabetes. Penyebabnya yang lain adalah umur sehingga komplikasi terjadi lebih cepat. Sebanyak 3 orang responden yang menderita diabetes kurang dari 5 tahun di penelitian ini masingmasing berada pada rentang umur 55-59 tahun yang berarti mulai memasuki fase usia lanjut atau usia lanjut dini.

Seseorang yang mengalami diabetes, penurunan sensasi kakinya lebih cepat, selain karena proses fisiologis menua juga diperparah dengan adanya efek dari kondisi hiperglikemi. Dari 3 responden ini ketika diperiksa 2 diantaranya memiliki kadar gula darah yang tinggi yaitu $>150 \mathrm{mg} / \mathrm{dL}$. Tingginya kadar gula dalam darah menyebabkan aktivitas jalur poliol meningkat seperti AGE's dan Protein Kinase $C$ (PKC). Aktivasi berbagai jalur tersebut berujung pada kurangnya vasodilatasi pembuluh darah saraf yang menyebabkan saraf tidak menerima nutrisi dan oksigen yang cukup yang pada akhirnya berujung pada kerusakan saraf itu sendiri ditandai dengan terjadinya neuropati diabetik.

\section{KESIMPULAN}

Berdasarkan hasil penelitian dan pembahasan pada BAB IV dapat di rumuskan kesimpulan. Diketahui lama menderita penyakit pada pasien diabetes mellitus tipe II dan kejadian komplikasi Polineuropati Diabetik di Wilayah Kerja Puskesmas Perumnas Antang, Kecamatan Manggala, Kota Makassar. Terdapat hubungan lama menderita diabetes mellitus tipe II dengan kejadian komplikasi polineuropati diabetik di Wilayah Kerja Puskesmas Perumnas Antang, Kecamatan Manggala, Kota Makassar.

\section{SARAN}

Berdasarkan hasil dari penelitian ini, peneliti memberikan saran agar dilakukan penelitian lebih lanjut dengan sampel yang lebih besar agar mendapatkan hasil yang lebih akurat.

Kepada para penderita diabetes melitus agar dapat mempertahankan kendali glukosa darah dan melakukan perawatan kaki sebaik-baiknya sesuai dengan yang dianjurkan oleh petugas kesehatan dan menjalankan perilaku hidup sehat dengan diabetes melitus.

Dan untuk tenaga kesehatan agar dapat menerapkan skrining polineuropati diabetik bagi pasien penderita diabetes. Khususnya kepada perawat agar lebih meningkatkan peran sebagai pemberi asuhan keperawatan dan edukator, mengingat neuropati diabetik merupakan komplikasi kronik dengan berbagai faktor resiko yang terlibat, maka dalam pengelolaan neuropati diabetik perlu melibatkan banyak aspek seperti perawatan kaki, pengendalian glukosa darah, terapi obat, serta edukasi kepada diabetes tentang bahaya kurang atau hilangnya sensasi rasa di kaki.

\section{UCAPAN TERIMA KASIH}

Ucapan terima kasih yang tentu tidak mencukupi hanya disampaikan dengan sekedar kata. Terkhusus untuk kedua orang tua saya yang tiada hentinya memberi motivasi dengan limpahan kasih sayang, perhatian, pengorbanan dan doa yang tiada hentinya sehingga penulis dapat menyelesaikan skripsi ini.

\section{DAFTAR PUSTAKA}

Aghnia, Rofana. (2017) Hubungan Lama Menderita Diabetes Mellitus dengan Terjadinya Diabetic Perpheral Neuropathy pada Penderita Diabetes Mellitus Tipe II di GRHA Diabetika Surakarta.

Booya, F., Bandarian, F., Larijani, B., Pajouhi, M., Nooraei, M, \& Lotfi, J. (2005). Potential risk factors for diabetic neuropathy : A case control study. BMC Neurol, 5, 24.

Dorland. (2015) Kamus Saku Kedokteran Dorland Edisi 8. Elsevier.

FKUI. (2018) Penatalaksanaan Diabetes Mellitus Terpadu. Jakarta: Badan Penerbit FKUI.

HR, Hasdianah, (2018) Mengenal Diabetes Mellitus. Yogyakarta: Nuha Medika.

IDF. (2015), (December). Retrieved from https://www.who.int/leishmaniasis/burden/en/ 
Jurnal Media Keperawatan: Politeknik Kesehatan Makassar

Vol. 10 No. 22019

e-issn : 2622-0148, p-issn : 2087-0035

Masturoh, Anggita (2018) Metodologi Penelitian Kesehatan: Kemenkes RI.

Nuari N. (2017). Strategi Manajemen Edukasi Pasien Diabetes Mellitus. Yogyakarta: Deepublish.

Nursalam. (2017). Metodologi Penelitian IImu Keperawatan: Pendekatan Praktis. Jakarta: Salemba Medika.

Prima Hari Nastiti, Achmad Hanif (2018). Hubungan Senam Prolanis Terhadap Kadar Gula Darah Puasa dan KGD2PP Pasien DM Tipe II. Universitas Muhammadiyah Surabaya

Setiati, Siti. (2014) Buku Ajar IImu Penyakit Dalam Jilid III Edisi IV. Jakarta: Interna Publishing.

Sudibyo Supardi, Rustika. (2013) Buku Ajar Metodologi Riset Keperawatan. Jakarta: Trans Info Media.

Syamsiah Nur. (2017) Berdamai dengan Diabetes. Jakarta: Tim Bumi Medika.

World Health Organization. (2018) Diabetes. Retrived from: https://www.who.int/en/news-room/factsheets/detail/diabetes

Yusra, A. (2011). Hubungan Antara Dukungan Keluarga Dengan Kualitas Hidup Pasien Diabetes Meliitus Tipe UU Di Poliklinik Penyakit Dalam Rumah Sakit Umum Pusat Fatmawati Jakarta. Universitas Indonesia dalam http://lib.ui.ac.id diakses 04 Juli 2019.

Zimmet, P. (2009) Preventing Diabetic Complication: A Primary Care Prospective, Diabetes Res Clin Pract 107-116. 